\title{
Mid-winter ultrastructural changes in the vegetative embryonic shoot of Norway spruce [Picea abies (L.) Karst.]
}

\author{
Marzenna GuZICKA ${ }^{\mathrm{a} *}$, Adam Woź NY \\ a Polish Academy of Sciences, Institut of Dendrology, ul. Parkowa 5, 62-035 Kórnik, Poland \\ ${ }^{b}$ Laboratory of General Botany, Faculty of Biology, Adam Mickiewicz University, al. Niepodległości 14, 61-713 Poznań, Poland
}

(Received 18 September 2001; accepted 25 September 2002)

\begin{abstract}
Ultrastructural changes in the winter embryonic shoot of Norway spruce are described. In January some cell elements did undergo considerable changes, even within several days, while morphological and anatomical changes were not observed. These ultrastructural changes were observed primarily within plastids (starch accumulation) and tannin vacuoles (the disappearance of aldehyde groups). A glucose released from tannins seems to be utilized for starch synthesis at the time of breakage of winter dormancy.
\end{abstract}

plastid / starch / tannin vacuole

Résumé - Changements ultrastructuraux de la tige embryonnaire végétative de Picea abies en hiver. Les changements ultrastructuraux de la tige embryonnaire végétative d'épicéa durant l'hiver sont décrits. En janvier, on n'observe pas de changements morphologiques ni anatomiques. On observe par contre, en l'espace de quelques jours seulement, des changements considérables au niveau cellulaire. Ceux-ci concernent avant tout les plastes (accumulation d'amidon) et les vacuoles à tanins (disparition des groupes aldéhydes libres). Ces changements peuvent être provoqués par différents facteurs dont la température paraît être le plus important. Le glucose libéré des tanins est probablement utilisé dans la synthèse d'amidon au moment de la sortie du repos hivernal.

plaste / amidon / vacuole à tanins

\section{INTRODUCTION}

Although there are several important monographs on spruce $[2,17]$, our knowledge of many aspects of its development is still poor. Some information on the microscopic structure of spruce buds has been published (e.g. [5, 8, 13]), but most of it does not concern Norway spruce. Thus the knowledge of changes in the structure and ultrastructure of embryonic shoot is still insufficient. The aim of this study was to determine whether changes take place in the submicroscopic structure of the distal part of an embryonic Norway spruce shoot during winter dormancy (January). The results presented in this study provide data on the period when changes in spruce embryonic shoot were not observed and the period when the changes may indicate that the winter dormancy of buds is broken. The possibility of determining when dormancy breakage takes place may also be important for some practical reasons.

\section{MATERIAL AND METHODS}

Buds were collected from grafts of Picea abies (L.) Karst. clone 04-118 (Serwy) in a clonal archive at the 'Zwierzyniec' Experimental Forest near Kórnik $\left(52^{\circ} 15^{\prime} \mathrm{N}, 17^{\circ} 04^{\prime} \mathrm{E}\right)$. The grafts were 20 years old. Material was collected from the middle part of the tree crown every week from 20th January till May 2000. In this paper only results of an analysis of material collected on 20th and 28th January 2000 is described, because during this period significant changes were observed. At each collection 35 buds were taken, 20 for light microscopy and 15 for electron microscopy.

Embryonic shoots were isolated from the buds and separately treated with two different fixatives and subsequent procedures:

(1) chromium-acetate fixative (CrAF), then embedding in paraffin wax; $9-\mu \mathrm{m}$ sections made by a rotatory microtome, and subjected to the PAS (periodic acid Schiff) reaction ([1], modified by [7]) which is a method of histochemical detection of polysaccharides. The reaction consists in oxidation of polysaccharides with periodic acid, so that aldehyde groups are formed. The aldehyde groups stained an intense purplish red colour with Schiff's reagent. As a result of the PAS reaction, not only starch grains, but also cellulose cell walls and tannin vacuoles in pith cells were stained.

(2) $3 \%$ glutaraldehyde and $2 \%$ paraformaldehyde with $\mathrm{CaCl}_{2}$ in $0.1 \mathrm{M}$ cacodylic buffer of $\mathrm{pH} 6.8$ (all reagents: Poliscience) postfixed in $1 \% \mathrm{OsO}_{4}$ at room temperature, in $0.1 \mathrm{M}$ cacodylic buffer; contrasting with uranyl acetate; dehydration in an ascending series of ethanol, followed by embedding in epoxy resin of low viscosity [18]. Ultrathin sections were made with diamond knives and an ultramicrotome, contrasted with uranyl acetate and lead citrate, and photographed under a

\footnotetext{
*Corresponding author: karotka@ poczta.onet.pl
} 
transmission electron microscope JEM 1200 EX II (JEOL) at an accelerating voltage of $80 \mathrm{keV}$. Semi-thin sections were made with glass knives, stained with methylene blue and basic fushin [9], and photographed under a light microscope.

A scanning electron microscope (Philips 515) was used for morphological observations. Fixation and the other treatments were the same as for the transmission electron microscope. The specimens were critical point dried in a Balzers CPD-030 unit with $\mathrm{CO}_{2}$ as a transition fluid and coated with gold using a Balzers SPD-050 sputter coater. Finally the embryonic shoots were observed and photographed in a Philips 515 scanning electron microscope at an accelerating voltage of $15 \mathrm{keV}$.

\section{RESULTS}

\subsection{Structure of the embryonic shoot and of the apical meristem}

In January the mean length of the bud was $7 \mathrm{~mm}( \pm 3 \mathrm{~mm})$. Embryonic shoots isolated from the buds were about $1 \mathrm{~mm}$ long. The needle primordia are spirally arranged on the shoot axis [Fig. 1(1)]. Width of the apex, measured on a longitudinal section along a line linking axils of the youngest two needle primordia, was about $0.2 \mathrm{~mm}$. Apex height, i.e. the distance from the tip to the lower border of the rib meristem measured along the shoot axis, ranged from 0.07 to $0.10 \mathrm{~mm}$. The apex showed a zonation typical of the class Coniferopsida.

\subsection{Buds collected on 20th of January 2000}

\subsubsection{Apical initials [Fig. 1(2)]}

Outer tangential walls of apical cells were thicker than anticlinal walls and inner tangential walls. The surface of outer tangential walls was covered with a thin, electron-opaque cuticle. The homogeneous, moderately electron-transparent cytoplasm contained numerous ribosomes, usually monosomal, rarely polysomal. A large nucleus was located at the cell centre. Chromatin of most nuclei was intermediate between chromeric and reticulate, but in some nuclei it was reticulate. Nucleoli of the compact type occurred usually in pairs, although some cells contained 1 or 3 nucleoli. Mitochondria (usually about 25 per cell section) were small, rounded, oval, or - less frequently - elongated. In some cases they were hour-glass-shaped. The endoplasmic reticulum with few, evenly distributed elements, was either rough or smooth. Only few, small vacuoles were present both in the polar and in the central parts of the cell. Some of them contained minute, electron-opaque, spherical structures. In the cytoplasm of some cells there were single rounded lipid bodies, moderately osmophilic, of similar size as the mitochondria. Proplastids, usually up to 8 per cell section, were electron-opaque and slightly larger than mitochondria. Most of them were irregular in shape, but some were oval or elongated, or even hour-glassshaped. Some proplastids contained vesicles or short thylakoids, either free or still attached to the inner membrane. Sometimes a few, small plastoglobuli and 1-2 small starch grains were observed, nevertheless PAS reactions and a polarising microscope failed to detect starch grains.

\subsubsection{Peripheral meristem [Figs. 1(3) and 1(4)]}

Cells of this zone were similar to cells of the apical zone, although their vacuolisation was sometimes slightly stronger.
Some cells contained rounded, moderately osmophilic lipid bodies, more numerous than in the apical cells [Fig. 1(4)].

\subsubsection{Young pith of the subapical zone [Figs. 1(5)-1(7)]}

As opposed to apical initial cells [Fig. 1(2)] and peripheral meristem cells [Fig. 1(3)], the distribution of various structures within pith cells was polarised, i.e. the nucleus was located opposite to vacuoles [Fig. 1(5)].

Tangential walls of pith cells were often irregularly thickened [Fig. 1(6)]. Numerous plasmodesmata were visible in all walls. The cytoplasm, as in meristematic cells, was moderately electron-transparent, and contained chiefly numerous monosomal ribosomes. The nucleus was usually peripheral, of various shape (elongated, lobed or oval), with chromeric chromatin [Fig. 1(5)] and usually two nucleoli of the compact type. Rounded mitochondria, with few wide cristae [Fig. 1(7)], were quite numerous: $21-39$ per cell section. The centre of the cell was occupied by a large, smooth tannin vacuole. In pith cells two types of tannin vacuoles could be distinguished, but only one type was present in each cell [Figs. 1(5) and 1(6)]. Most cells contained vacuoles of the first type, with a homogeneous, electron-opaque interior. Tannin vacuoles of the second type were filled with flocculent structures and they were rare [Fig. 1(6)]. Pith cells contained also small peripheral electrontransparent vacuoles, often numerous [Figs. 1(5)-1(7)]. Plastids, usually 5-11 per cell section, formed aggregations near the nucleus. They were much larger than mitochondria, elongated, lens-shaped or irregular [Fig. 1(7)]. The presence of a system of thylakoids enabled their identification as chloroplasts. In most chloroplasts thylakoids formed long grana, similar to those found in algae. Numerous vesicles were present in the stroma of some chloroplasts. Few plastids contained plastoglobuli or starch grains (the latter were larger and more numerous than in cells of the apical cells).

\subsection{Buds collected on 28th January 2000}

The morphological and anatomical structure of embryonic shoot was the same as on the previous date. However, some cytological changes could be noticed. Starch was much more abundant, so it could be detected under a light microscope [after the PAS reaction - Figs. 2(9A) and 2(9B)]. It was observed particularly at the basal part of needle primordia, and in the young pith. Starch was also present in procambial cells and in whole apical meristem, especially in the rib meristem. Starch grains were least abundant in the apical initials.

Differences also concerned the character of tannin vacuoles [Figs. 2(8) and 2(9)]. In the material collected on 20th of January most of them stained red after the PAS reaction [Figs. 2(8A) and 2(8B)]. In the material collected on 28th of January the pith cells at the base of the embryonic shoot and some pith cells of the subapical zone contained unstained, yellow vacuoles [Figs. 2(9A) and 2(9B)].

\subsubsection{Apical initials}

The number of lipid bodies increased in cells of this zone. Also starch grains were larger. 

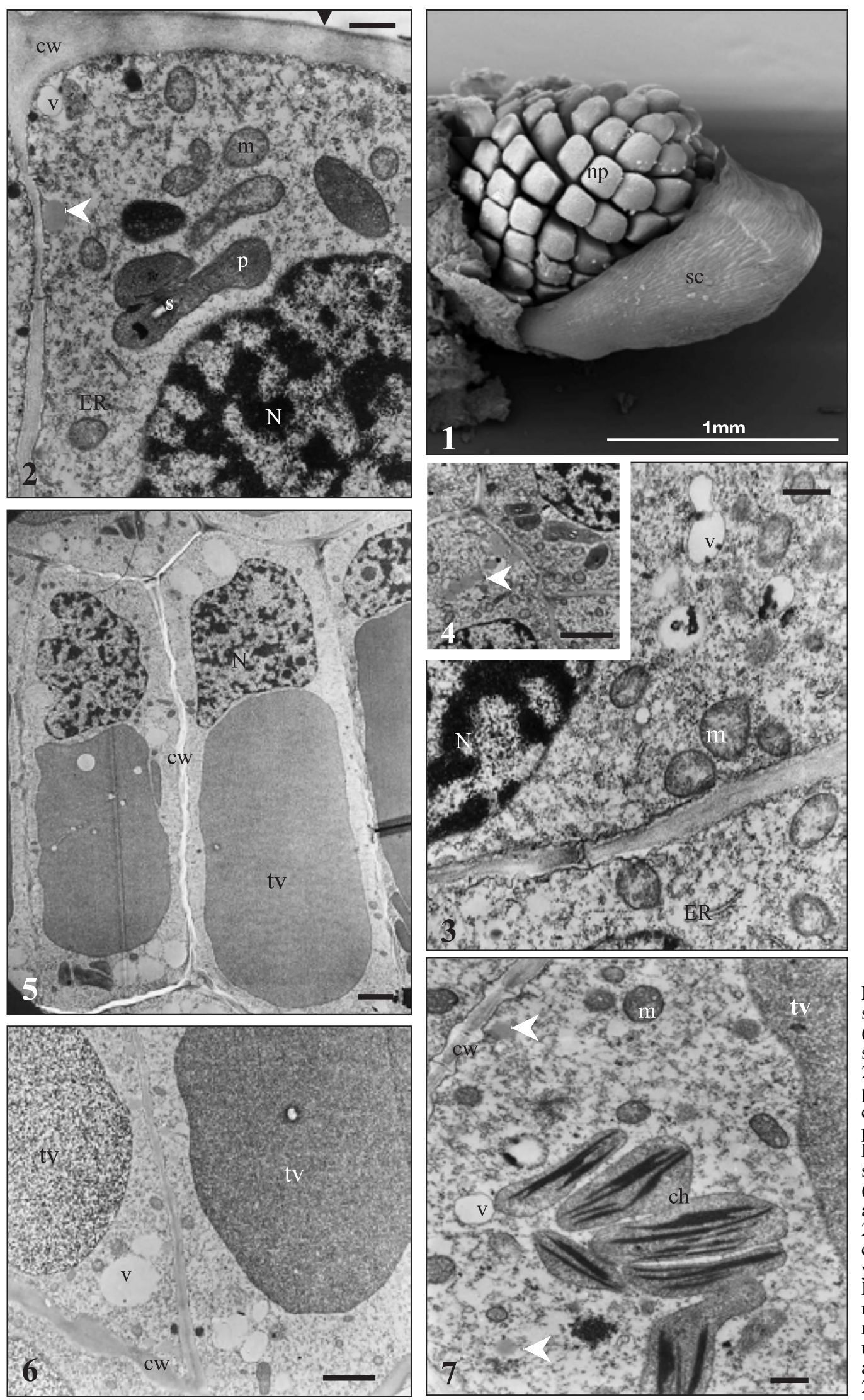

Figure 1. (1) An embryonic shoot of Picea abies in winter (SEM). np: needle primordium, sc: scale. (2-4) Bud collected 20.01. (2) apical initials; $(3,4)$ peripheral meristem; TEM. $\mathrm{cw}$ : cell wall; $\mathrm{N}$ : nucleus; $\mathrm{p}$ : proplastid; m: mitochondrion; ER: endoplasmic reticulum; s: starch; v: vacuole; black arrow (2): a layer of cuticle; white arrow (4): lipid body. Bar: (4) $2 \mu \mathrm{m}$, (2, 3) $500 \mathrm{~nm}$. (5-7) Bud collected 20.01; distal part of young pith; TEM. cw: cell wall; $\mathrm{N}$ : nucleus; ch: chloroplast; $\mathrm{m}$ : mitochondrion; ER: endoplasmic reticulum; s: starch; v: vacuole; tv: tannin vacuole; white arrow (7): lipid body. Bar: $(5,6)$ $2 \mu \mathrm{m}$, (7) $500 \mathrm{~nm}$. 

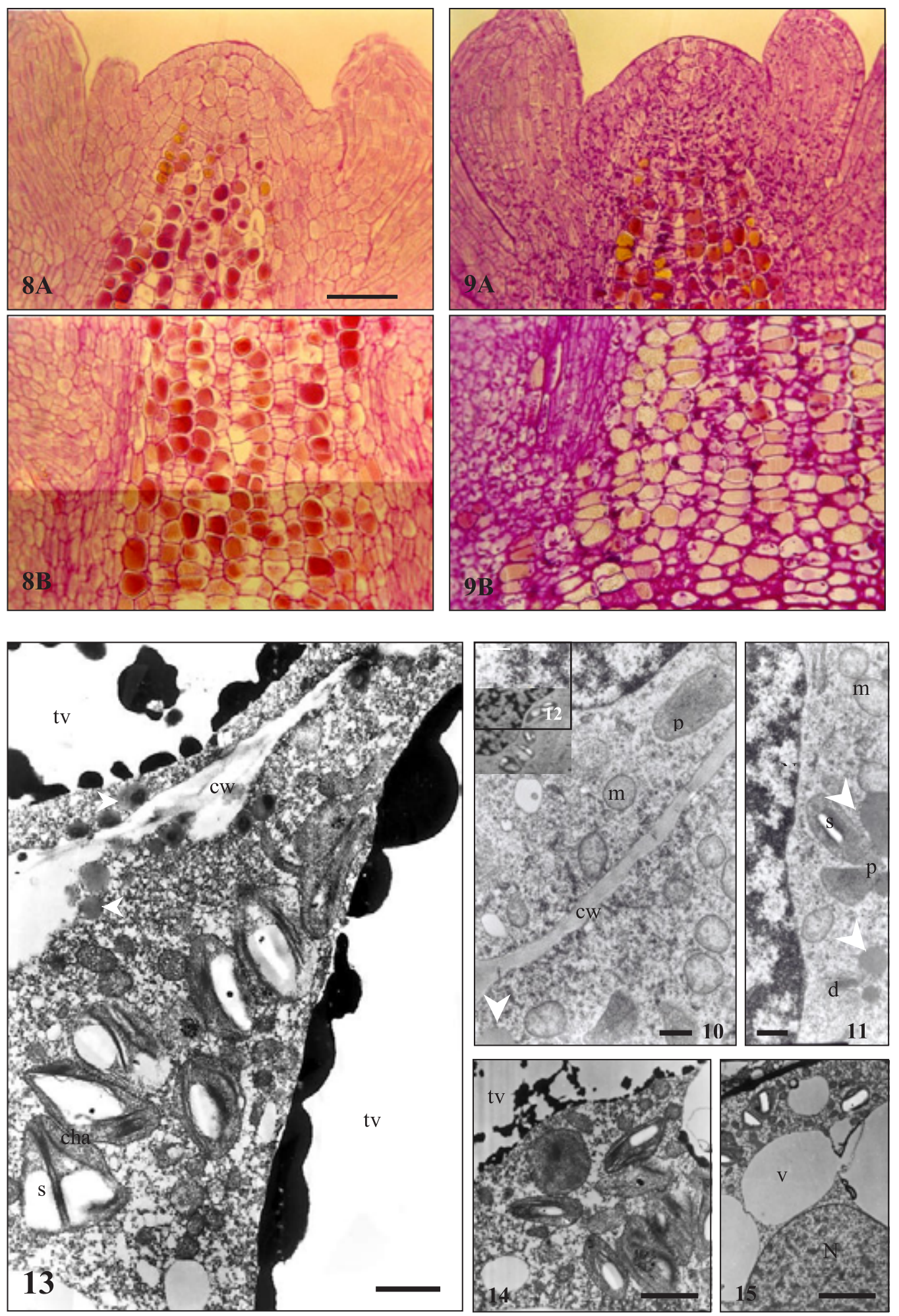

Figure 2. (8) Bud collected 20.01, PAS reaction. (A) Central longitudinal section of the apex; (B) basal part of the embryonic shoot. The majority of tannin vacuoles in pith cells stained an intense purpurish red colour. Starch was not detected in cells. (9) Bud collected 28.01, PAS reaction. (A) Central longitudinal section of the apex; (B) basal part of the embryonic shoot. Starch is visible as small spots. Bar: (8-9) 0.09 mm. (10-15) Bud collected 28.01; (10-12) peripheral meristem; (13-15) distal part of young pith; TEM. cw: cell wall; N: nucleus; p: proplastid; cha: chloroamyloplast; s: starch; m: mitochondrion; ER: endoplasmic reticulum; d: dictiosom; v: vacuole; tv: tannin vacuole; white arrow (10 and 11): lipid body. Bar: $(10,11) 500 \mathrm{~nm},(13,14) 1 \mu \mathrm{m},(12,15) 2 \mu \mathrm{m}$. 


\subsubsection{Peripheral meristem}

The number of plasmodesmata in cell walls was higher than earlier. The cytoplasm contained more abundant rough endoplasmic reticulum, often located near cell walls [Fig. 2(10)]. Lipid bodies were larger, found in nearly all cells of this zone. The number, shape and distribution of mitochondria were the same as previously. Three or four dictiosomes were found, each composed of usually 5 cisternae. Margins of the cisternae were only slightly swollen, and few vesicles were present [Fig. 2(11)]. Unchanged proplastids contained somewhat larger starch grains [Fig. 2(12)].

\subsubsection{Young pith of the subapical zone}

Changes within cells of this zone concerned mainly the character of tannin vacuoles and plastids. Cells with an electron-opaque, homogeneously granular interior were much rare than in the material collected 8 days earlier. Cells with flocculate vacuoles were present as before but additionally, a third type of vacuoles was observed in which tannins formed homogeneous, osmophilic bands with thickenings, located near the tonoplast. The central part of the vacuole was electron-transparent [Fig. 2(13)]. The numbers and distribution of plastids did not change, but chloroplasts transformed into chloroamyloplasts containing large starch grains, or even into amyloplasts [Figs. 2(13)-2(15)]. Long thylakoids, usually stacked in few low grana were present in some chloroamyloplasts. Plastoglobuli were more numerous, smaller and more osmophilic. As a rule, they formed compact groups. In some pith cells, mainly near the walls, few lipid bodies appeared.

\section{DISCUSSION}

With respect to the morphological and anatomical structure, the analysed winter embryonic shoots of Norway spruce did not differ from those described by other authors in this species and in other species of the genus Picea $[5,8,13]$. However, considerable differences in starch content and cell ultrastructure could be observed between the two dates of collection.

Staining with methylene blue did not enable detection of differences, but the PAS reaction and transmission electron microscope revealed the differences. The changes were observed primarily in plastids, as their starch content increased remarkably.
Many authors have reported that starch present in meristematic cells in the autumn disappears in December and reappears in late March (e.g. in Populus euramericana [15], Rhododendron maximum [12]). This can be noticed also in conifers. In the shoot apical meristem of pine intensive starch accumulation can be observed in a transmission electron microscope in early autumn [10]. From December till February, starch gradually decreases, and in early spring it markedly increases again. Observations of pine buds under a light microscope show that starch is absent in winter and reappears in March [7]. Also in a spruce winter bud no starch has been detected [8]. In other study the chloroplast ultrastructure in vegetative buds of spruce was characterised by relatively large starch grains. There were no changes during autumn and winter [11]. In the present study starch in a spruce bud was found in the embryonic shoots during winter. However, the starch grains were so small that they can be detected only with transmission electron microscopy. This study revealed that starch content of plastids increased dramatically within several winter days. The results presented here and some earlier data [4] show that during winter changes in starch content may be much faster than reported until now.

Interesting changes were observed also in tannin vacuoles. In the material collected on 20th of January, the majority of tannin vacuoles stained an intense purplish red colour. A week later the majority of tannin vacuoles were yellow (unstained). This suggests that the number of aldehyde groups has decreased so much that they ceased to be detectable by the PAS reaction. The relationship between starch synthesis and glucose released from tannins has been postulated by Hejnowicz [6-8] for both spruce and pine. Our observations suggest that this hypothesis is true. The decrease in the number of vacuoles stained in an intense purplish red colour as a result of the PAS reaction, and the increase in the number of yellow vacuoles was clearly synchronised with starch accumulation. This suggests an association with release of glucose from tannins, and with its utilisation for starch synthesis. Embryonic shoots of spruce contain mainly hydrolysable tannins, and only small amounts of condensed tannins (unpublished data). It is noteworthy that starch was accumulated very early in pith cells. Changes in vacuoles and plastids were also confirmed by transmission electron microscopy observations.

Obviously, the photosynthesis is another potential source of starch. However, the minimum temperature enabling photosynthesis is $-5{ }^{\circ} \mathrm{C}[14,16]$. The climatic diagram (Fig. 3)

\section{Mean temperature of January 2000}

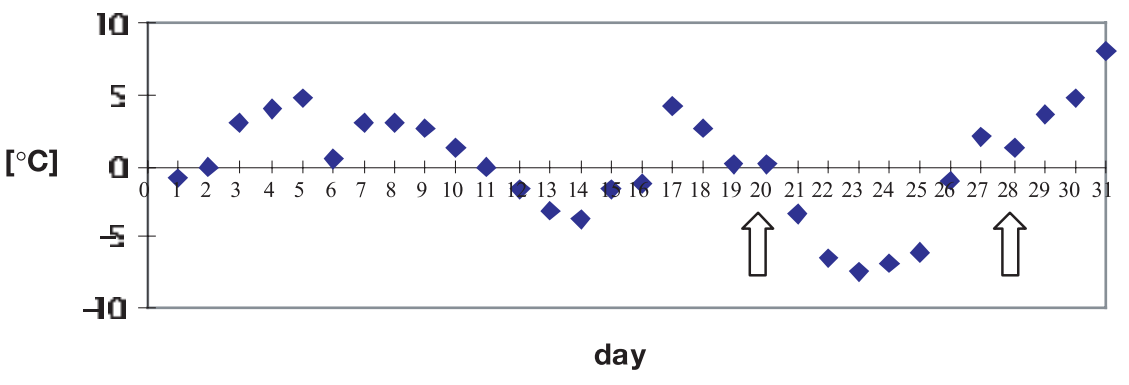

Figure 3. Mean temperature of January 2000 (arrows indicate the dates of collection). 
shows that in the period immediately preceding starch accumulation, temperatures were very low. By contrast, relatively high temperatures were recorded in early January, but it was not resulted in the starch accumulation. It also seems that starch accumulation did not result from conversion of lipids to starch, because in cells of shoot primordia (in contrast to pine trees, [3]), only single lipid bodies were observed occasionally, and the number of them did not change during the study period.

All above mentioned ultrastructural changes in an embryonic shoot were first observed on January 28. No such changes were observed in the first three weeks of January, although studies were conducted for several years (some of the observations were already published [4]). Thus it can be concluded that during winter dormancy the submicroscopic structure of embryonic shoot may undergo considerable changes, despite of the lack of morphological differences.

Acknowledgements: This work was supported by a grant from the Polish State Committee for Scientific Research No. 5 P06H 02019. We warmly thank Dr. Alina Hejnowicz and Prof. W. Chałupka for their valuable comments during preparation of this manuscript.

\section{REFERENCES}

[1] Berlyn G.P., Miksche J.P., Botanical microtechnique and cytochemistry, Iowa State University, Ames, IA, USA, 1976.

[2] Boratyński A., Bugała W. (red.), Biologia świerka pospolitego, Bogucki Wydawnictwo Naukowe, Poznań, 1998, p. 781 (in Polish).

[3] Cecich R.A., Development of vacuoles and lipid bodies in apical meristem of Pinus banksiana, Am. J. Bot. 66 (1979) 895-901.

[4] Guzicka M., Changes in starch distribution within an embryonic shoot of Norway spruce [Picea abies (L.) Karst.] before resumption of mitotic activity, Dendrobiology 46 (2001) 27-31.
[5] Harrison D.L.S., Owens J.N., Bud development in Picea engelmannii. I. Vegetative bud development, differentiation and early development of reproductive buds, Can. J. Bot. 61 (1983) 2291-2301.

[6] Hejnowicz A., Tannin vacuoles and starch in the development of Scots pine (Pinus sylvestris L.) vegetative buds, Act. Soc. Bot. Pol. 48 (1979) 195-203

[7] Hejnowicz A., Budowa i rozwój wegetatywnych paków sosny zwyczajnej (Pinus sylvestris L.). Instytut Dendrologii PAN, Kórnik, 1982, p. 105 (in Polish with English summary).

[8] Hejnowicz A., Obarska E., Structure and development of vegetative buds, from the lower crown of Picea abies, Ann. Sci. For. 52 (1995) 433-447.

[9] Humprey C.D., Pittman F.E., Methylen blue - azure II and basic fushin, Stain Technol. 42 (1974) 9-14.

[10] Koteyeva N.K., Ultrastructural changes in shoot apical meristem cells of Pinus sylvestris (Pinaceae) in annual cycle. Bot. Zurnal 82 (1997) 10-23.

[11] Lepedus H., Cesar V., Ljubesic N., Chloroplast ultrastructure and chlorophyll levels in vegetative buds and needles of Norway spruce (Picea abies L. Karst.), Period. Biol. 103 (2001) 61-65.

[12] Lynch D.V., Rivera E.R., Ultrastructure of cells in the overwintering dormant shoot apex of Rhododendron maximum L., Bot. Gaz. 142 (1981) 63-72.

[13] Owens J.N., Molder M., Bud development in Sitka spruce. I. Annual growth cycle of vegetative buds and shoots, Can. J. Bot. 54 (1976) 313-325.

[14] Pisek A., Larcher W., Unterholzner R., Kardinale temperaturbereiche der photosynthese und grenztemperaturen des lebenes der blätter verschiedener spermatophyten. I. Temperaturminimum der netto-assimilation, gefrier- frostschadensbereiche der blätter. Flora, Abt. B 157 (1967) 239-264.

[15] Sagisaka S., A cold environment is a prerequisite for formation of "plastid initials" in winter buds of poplar, Plant Physiol. 99 (1992) $1657-1663$

[16] Salageanu A., Atanasiu L., Yearly cycle of photosynthesis in certain evergreen plants and autumn wheat, Biol. Rev. 7 (1962) 1-6.

[17] Schmidt-Vogt H., Die Fichte. Verlag Paul Parey, Hamburg und Berlin, Band 4, 1989

[18] Spurr A.R., A low - viscosity epoxy resin embedding medium for electron microscopy, J. Ultrastruct. Res. 26 (1969) 31-43. 